каждом конкретном случае. Портрет любого персонажа в романе обусловлен и взаимозависит от всей суммы художественных средств. Он представлен в романе настолько полно и отчетливо, что он дает четкое представление о психологической характеристике и социальном облике героя. Посредством портрета Л. Кокышев показывает и свое отношение к героям. Таким образом, стилистическое единство в создании портрета, так же, как и в употреблении произведения, предопределяется прежде всего национальными истоками. Нам удалось выделить следующие отдельные типы портретов в романе «Арина»: статичный, психологический, лейтмотивный портреты.

Переводчику наиболее удачно удалось воссоздать статичный и романтический портреты. Исследование типов портретных характеристик дает возможность утверждать о существовании ритма внешнего облика персонажей, его текучесть.

1. Кокышев, Л. Арина: роман / Л. Кокышев; пер. с алт. А. Китайника. - М. : Сов. Россия, 1985. - 224 c.

2. Кокышев, Л. Арина : романы / Л. Кокышев; ауд. Н. Төлеупов. - Алматы: Жазушы, 1972. - 260 б.

3. Казахско-русский словарь / под ред. К. В. Сагындыкова. - Алматы, 2017.

4. Казакова, Т. А. Теория перевода (лингвистические аспекты) / Т. А. Казакова. - Спб : Союз, 2001. $142 \mathrm{c}$.

5. Сепир, Э. Избранные труды по языкознанию и культурологи / Э. Сепир. - М., 1993. - 656 с.

\title{
Lebedeva V.V. \\ A Comparative Analysis of the Korean and Yakut Languages. Onomatopoetic Words
}

North-Eastern Federal University named after M.K. Ammosov (Russia, Yakutsk)

doi: 10.18411/lj-05-2020-183

idsp: ljournal-05-2020-183

\section{Аннотация}

Эта статья посвящена сопоставительному анализу корейских и якутских звукоподражательных слов. В рамках данной статьи дается характеристика морфологических, фонетических, лексических и семантических особенностей звукоподражательных слов корейского и русского языков на материале трудов Поливанова Е.Д., Chae Wan, Kay Won Lee по корейской лингвистике и Харитонова Л.Н., Кулаковского А.Е. по якутской лингвистике.

Ключевые слова: ономатопоэтическая лексика, агглютинативный язык, имитация, звук, гласный, согласный.

\section{Abstract}

This article focuses on the comparative analysis of Korean and Yakut onomatopoeic words. The research describes the morphological, phonetic, lexical and semantic features of the onomatopoeic words in the Korean and Russian languages based on the works of Polivanova E.D., Chae Wan, Kay Won Lee on Korean linguistics and Kharitonov L.N., Kulakovsky A.E. on Yakut linguistics.

Keywords: onomatopoetic words, agglutinating language, imitation, sound, vowel, consonant.

Onomatopoetic words play an exceptional role in both, the written speech and oral speech in the agglutinating languages. Both languages that we are analyzing belong to this type of languages. Finding out the functional peculiarities of the onomatopoetic words from the point of view of interlinguistic comparison can help in understanding the specific features of Korean and Yakut linguistic culture. 
Having studied the works on onomatopoetic words written by such outstanding linguists as Polyvanov E.D., Chae Wan, and Kay Won Lee on Yakut linguistics, we attempted to compare the Korean and Yakut languages onomatopoetic words peculiarities. As a result, we have come to the following conclusions.

According to their meaning onomatopoetic words in the Korean and the Yakut languages are subdivided into two large groups: 1. Onomatopoetic words that imitate the sounds of different living beings and natural forces, or objects: For example, imitation of the cuckoo bird's singing뻐꾹뻐꾹 [ppeokkuk-ppeokkuk] (Korean), kuk-kook (Yakut); imitation of a person crying: 엉엉 [eong-eong] (Korean), iyy-iyy (Yakut); 2. Concept imitating words that give a representation about the movement living beings or light phenomena that occur on the same principle of peculiar imitation, but a transferred one to the sphere of the person's sensual reaction (visual perception, movement, somatic reaction):

For example, the image of a dazzle: 반짝반짝 (Korean), kulum-chagyl (Yakut), image of a curving, bumpy surface: 울퉁불퉁 (Korean), ollur-bollur (Yakut).

In his work the Korean linguist, Che Wan subdivides Korean onomatopoetic words into the following groups: 1. Onomatopoetic words connected with animals: 흐르릉흐르릉 [heureureung-heureureung] - the roar of a tiger, 아지쥬지 [aji-jyuji] - the singing of a swallow, 외옹외옹 [ueong-ueong] - the laughter of a horse, etc; 2. Onomatopoetic words connected with people: 풍덩 [p`ungdeong] - the sound of someone falling into the water, 후루룩 [hururuk] - the sound of one blowing his nose, 쇼근쇼근 [syogeun-syogeun] - the sound of a whisper, etc; 3. The sounds of the musical instruments: 동골동골 [donggoldonggol] - the sound of the small Korean drum with handle, 둥덩둥덩 [dungdeongdungdeong] - the sound of the Korean 12-stringed musical instrument, etc; 4. Other sounds including the remaining sounds that exist in the nature: 솰솰 [soal-soal] - the sound of the wind, 우루룩쥬루룩 [ururuk-jyururuk] - the sound of the rain, 필울울 [p`iruril] - the sound of a flying arrow, etc. [9, 212-224]

The onomatopoetic words in the Yakut language, unlike the ones in the Korean language can be classified more thoroughly. Words denoting sounds that are produced without using the vocal apparatus can be divided into the following subgroups: 1) Sounds produced by metal objects: dang, dong, lang, leeng, ling, tang, chang; 2) The sound of a gunshot and other loud and sharp sounds: bar, bas, dor, nyir, pang, pas, pus; 3) Hitting, knocking, clapping sounds of hard objects: kip, kup, lap, las, lis, tap, tas, pakh, tos, top; 4) Rattling and shaking sounds: dar, deer, dor, dir, der, dyor, tar, tor, tir; 5) Sounds produced by firm objects: bark, bir, birk, bot, byos, byul, kirk, lakh, lik, park, peerk, pyolk, pirk, tis, khal; 6) The sounds produced by viscous and semisolid substances: bal, bolk, bil, bilk, pal, palk; 7) Hissing and whistling sounds: kyup, kuus, saap, sark, sir, syuy, syup, syr, syyp, char; 8) The sounds of granular materials and small objects: kur, kyur, kyr, sur, syr, etc.

The group of words, denoting voices of the living beings can be divided into the several additional subgroups: 1) words denoting domestic animal sounds: ang, ong - the barking of a dog, annyakha - the laughter of a horse, byoyo, myoyo - a threatening roar of a bull, maa - the bellow of a cow; 2) word denoting the cawking and singing of birds: kyukkyuuk - the voice of a cuckoo bird, kylygylyk, lyk-lyk - the voice of a goose, tyuryu-tyuryu, tyuryuryuyuk - the voice of a crane, chychyp- chaap - the birds' twitter and singing; 3) Words denoting the small animal voices: char - the cry of the ermine, chyp-chyp, cheep-cheep - the sqeak of a chipmunk, chyyp - the squeak of a mouse; 4) Words denoting buzzing sounds and 
the sounds of squeaking bugs: syy-syy, yy-yy - the buzzing of a mosquitoes or gnats swarm, bach-bach - the quacking sound of a frog; 5) human sounds: byus - a loud sound of one sniffling through his nose, ha-ha-ha, ho-ho-ho, hu-hu-hu - laughter, uy-uy, iy-iy - a constant cry, khakh - a spitting sound, khar-khar - the sound of a deep cough.

It should be noted that in the Yakut language every sound in the root of the word performs a definite illustrative function in producing an exterior sound. Thus, the vowel sounds mostly reflect the tonality and various acoustic shades of the similar or the same sounds, creating synonymous units of the onomatopoetic roots [3, 369].

Wide vowels $(a(a), o(o), \theta(y o), \ni(e h))$ are mostly used to express open singsong-like sounds that have a clear tone: lang - the sound produced by large hollow metal objects (the ringing of a copper basin); dar - a loud rattling sound (a gunshot), lop - a loud sound of two hard objects surfaces hitting against each other, etc. Narrow vowels $(b l(y), u(i), y(u), Y(y u))$ usually reflect flat sounds without a clear tone: bir - the sound of a ripped firm surface, byl a thudding or a slapping sound, lung - a flat knock from a hit, etc. The front wide vowels $\ni(e)$, $\theta(y o)$ used instead of the back vowels $a$ and $o$, often express easiness and weakness of sounds: tap-tep, top-tep, tos-tes, etc.

Consonants play a more significant role in expressing the main quality of a sound. The final consonants characterize the sound's length and noise coloring. The well-resonating and long sounds are reflected by the sonorants $r$ and $n g$; the plosive $p, k$, $t$, on the contrary, reflect breaking and short sounds. The final $s$ consonant usually shows the sharpness of a produced sound: lys, tys -a light, flat crack, tas - a sharp hitting sound. The initial consonant sound often defines the peculiarity of the sound production's initial stage. The sharpness and unexpectedness of the sound production is caused by the plosive consonants: kyur - the sound of a sudden shatter of small fragments, tyung - a flat sound of a gunshot. The initial $s$ sound mostly appears in roots denoting whistling or hissing sounds: sap - the flap of wings, syr lard or oil hissing on a fire. The initial ch sound is commonly used in roots expressing sharp sounds with high tones: chyus - a sharp and short whistle, chyp - a short squeak or whistle [3, 370].

In the Korean language, a great number of synonyms are produced by changing the sounds in a word; each of these words is a variant or an equivalent of the initial word, which is a characteristic feature of the onomatopoetic words. There are two types of alternation in the Korean onomatopoetic words - the consonant alternation and vowel alternation. The alternation of vowels that have a semantic meaning creates special units, which consist of words that differ from each other only by their vowel components.

The expression of different quality sounds, movement, and manner defines this or that vowel sounds amount in image words. The vowels $\vdash[\mathrm{a}], \perp[\mathrm{o}]$ и $Н[\mathrm{e}]$ reflect the sounds, the bright, small, strong and tender movement and manner, but the sounds -1 [eo], $-[\mathrm{eu}], \mathrm{\top}$ [u] и | [i] express something dark, big, weak and heavy.

For example, 덜렁-덜렁 [deolleong-deolleong] - the ringing of a bell, but 딸랑딸랑 [dallang-dallang] - the ringing of a bell of a lower tune; 아장아장 - the footsteps of a child, but어정어정 [eojeong-eojeong] - the footsteps of a grownup man.

As for the consonants, as a rule, they alternated by weak stopping sounds ( $\neg$

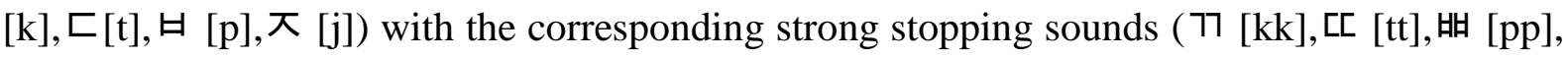
ㅈ $[\mathrm{jj}]$ ) or by the corresponding aspirated sounds ( $\exists\left[\mathrm{k}^{\prime}\right], E\left[\mathrm{t}^{\prime}\right], \bar{\perp}\left[\mathrm{p}^{`}\right]$, 天 $\left.\left[\mathrm{j}^{\prime}\right]\right)$. A weak fricative sound $\mathcal{\Lambda}[\mathrm{s}$ ] is also alternated by the corresponding strong sound $从$ [ss]. The consonant alternation in onomatopoetic words reflects the force of the produced sound, and the energy of the described object in the image words. $[2,10]$ 
For example: 솔솔 [sol-sol] - to warble (about the water or a stream); 쏠 쏠 [ssol-ssol] - to rattle (about a waterfall).

바삭바삭 [basak-basak] - crispy, crunchy; 파삭파삭 [p`asak-p`asak] - ломкий, crumbly.

Therefore, different variants of image words depending on the vowels or consonants in the word express an event or thing, when the main definition of the word remains the same, but the phonetic form of the word changes.

In both the Korean and the Yakut language, onomatopoeias consist of one or more syllables: one syllable - 쾅 [k`oang], lys; two syllables - 덜-컹 [deol-k`eong], ly-khyr; three syllables - 덜-커-덩 [deol-k`eo-deong], ly-khy-gyr. In both the Korean and the Yakut language there is a common usage of the closed syllable type (CVC) (짤깍짤깍 [jjalkkakjjalkkak], 절름절름 [jeolleum-jeolleum]), (tys, lyngkyr-langkyr). Reduplication is often used in both languages, as a means of giving a special coloring: 아장아장 [ajang-ajang] - about the persons's footsteps, 느릿느릿 [neurit-neurit]- slow body motion; tyn-tyn, - a thread of a sound, tys-tys - sound of a cracking object. Reduplication expresses a repeated appearance of the same image; it can also intensify the meaning of a word.

Хара5ын уута, ситэ сиргэ тиийбэккэ тонон, муус тобурах буолан, чигдигэ топmоn гына ту4эр (Kharaghyn uuta, syte syrge tyibekke tongon, muus toburakh byuolan, chygdyge top-top gyna tucher) $(1,34)$. (His tears fall like hailstorm and knock against the snow crust, freezing in the air). The given example shows tear drops that constantly fall one after another.

나는 좋아서 손뼉을 짤깍짤깍 [jjalkkak-jjalkkak] 쳤습니다. [8, 146] (I clapped my hands with joy).

This example shows how the person's hands clapped loudly together from joy.

There is also a wide use of sound alternations (울긋불긋 [ulgeut-pulgeut] multicolored, pus-pas - the sound of a gunshot). This example refers to the paired onomatopoetic and image words, where the second component of the first pair is usually a phonetic duplication of the second pair.

In the Korean language we can perform morphological broadening, where a part of the element (syllable) of the initial word repeats and as a result, there is a broader form: 후룩 [huruk] - (pulling-in sound) - 후루룩 [hururuk] - a longer and stronger sound of pulling in.

In both languages the image words are not used independently. They are unchangeable. Being a part of the sentence onomatopoetic units become grammatical categories and definite parts of speech. They are usually added into the sentence together with auxiliary verbs. In the Korean language, they are such verbs as 하다 [hada] и 거리다 [keorida] (to do).

For example: 만도의 두 눈에서 불이 번적했다 [beonjjeokhetta]. [8, 432] (Mando's eyes shone with fire). The image word번적 [beonjjeok] in this sentence is used with the verb 하다 [hada] in the past tense and the word "to shine" is also used in the past tense.

\section{기적소리가 가까워질수록 가슴이 울렁거렸다 [ulleongkeoryeutta]. [8, 432] (The} closer the sound of the siren, the faster the heart was thumping). The image word울렁 
[ulleong] in this sentence is used with the verb거리다 [keorida] in the past tense and therefore the verb "to thump" is also used in the past tense.

The verb gyn, which also means to do is used in the Yakut language.

For example: Appanaas syobyulekhen keghis gynna. [1, 35] (However, Appanas nodded to show he agrees). The image word keghis in this sentence is used with the verb gyn and gives the word "to nod".

Postpositions can be used in the Korean language along with the auxiliary verbs 스럽다 [seureopta], - 맞다 [matta], the same can be done in the Yakut language - kyurdyuk.

For example, - 스럽다 [seureopta]: 가량스럽다 (to seem untidy), 곰상스럽다 (to seem kind), 수럭스럽다 (to seem cheerful), 개걸스럽다 (to seem gluttonous), 게걸스럽다 (to seem dissatisfied); 맞다 [matta]: - 능청맞다 (cunning), 정들맞다 (disgusting).

- kyurdyuk: badyir kyurdyuk - with a solid rough surface, bal kyutdyuk - soft, wreathed khachyr kyurdyuk - too rough (about clothes).

Different parts of speech in the Yakut language can be formed by adding endings to the onomatopoetic words. For example, we can form the following verbs using onomatopoetic words: khachygyr (a crunching sound) - khachygyraa (to crunch), an adverb khachygyrachy (crunchy), an adjective - khachygyras (crunchy), a noun - khachygyraachy (the one, who crunches).

In the Korean language, like in the Yakut, the different parts of speech can be formed by adding and ending to the onomatopoetic word with the verb 거리다 [keorida]. For example, the word 반짝 [banjjak] (an illustrative image of something bright) can produce a verb - 반짝거리다 [banjjakkeorida] (to shine), an adverb - 반짝거리게 [banjjakeorige] (shiny), an adjective - 반짝거리는 [qksjjakkeorineun] (shiny), a noun - 반짝거리기 [banjjakkeorigi] (shine).

From the lexical point of view, onomatopoetic words cannot be used independently, because they are used only in combinations with other words. The formula "onomatopoetic adverb + verb" in the Korean language gives set expressions. There are a number of onomatopoetic adverbs that are used only with a definite verb. For example, specific words are used only with the verb웃다 [utta] (to laugh) and together they give the semantic shades of laughter: 깔깔 웃다 [kkal-kkal utta] - to laugh, 빙그레 웃다 [binggeure utta] - to smile kindly, 싱글벙글 웃다 [singgeul-peonggeul utta] - to be all smiles, 비식 웃다 [bisik utta] to smirk. The same goes for the verb 울다 [ulda] (to cry), used with the following verbs describing the different shades of a person's crying: 앙앙 울다 [ang-ang ulda] - a baby's cry, 엉엉 울다 [eong-eong ulda] - a loud cry, 딸락딸락 울다 [ttallak-ttallak ulda] - to cry one's heart out, 칭얼 울다 [j ingeol ulda] - to whine, to complain.

Single Yakut onomatopoetic word stems always need to have an auxiliary verbs gyn and dyie in postposition. Double or pair stems also partially need auxiliary verbs in postposition, and can partially be used without them by clinging to a notional verb in the form of an adverb [4, 59]. In this case, there are the so-called set word complexes or complex (compound) words: nyakh, diye, khoros gyn, kedes gyn, akh bar, etc. Chocho myuch-mach barda, tyugyu da etien byulbata [6, 18]. (Chocho fell silent, not knowing what to answer).

A significant feature of the Yakut image words is that they are not listed in any dictionary. A.E. Kulakovsky, one of the first Yakut people to study image words, came to a paradoxic conclusion: to throw the image words out of the dictionary. He came to this 
conclusion from a close observation. A.E. Kulakovsky thought that image words do not have a "specific public spirit". By saying "the words" public spirit", he meant their common use in speech. As he stated "each person repeatedly makes them up in speech". A.E. Kulakovsky called image words "picturesque". Signifying the uniqueness of these words, he wrote: "The Yakut picturesque words are produced by some secret linguistic laws and will remain an unsolved mystery for the linguists in the future". There are a large number of these words and it cannot be estimated, because, as I've mentioned before, they are created in completely different circumstances". Thus, he was the first writer to notice that image words are far beyond the range of regular words [7, 125].

The Korean onomatopoetic words, on the contrary, are included in the dictionaries and are commonly used and not repeatedly created each time, but they are produced in speech.

Image words most commonly appear in the fiction, performing various expressive functions. In both the Korean and the Yakut languages, fiction contains a great amount of onomatopoetic words; a number of these words can be used in one sentence. For example, in Korean: 손에 매달린 고등어가 대고 달랑달랑 [dallang-dallang] 춤을 춘다, 너무 급하게 들이부어서 그런지, 만도의 뱃속에서는 우글우글 [ugeul-ugeul] 술이 끓고 다리가

휘청거린다 [hichung-huichung]. [4,435] (the mackerel, hanging in a hand, danced while swinging, and maybe because of the vodka that was drunk so fast, the stomach roared, and because of that he staggered). In Yakut: Khara tya tyacha tygynes buolbut, tyachaabat uulaah tyympy ebetyn dolgunun tyacha nyillygyres buolbut. (The taiga hoots and moans, the lake, usually very quiet, rages, and raves).

Thus, in comparing the Yakut and Korean language onomatopoetic words, we can distinguish many similarities, on all levels: the mythological, phonetic, lexical, and stylistic. In the future, we plan to make a thorough study of the phonetics variants' semantic peculiarities of the image words in the languages under comparison and their stylistic usage in speech.

\section{$* * *$}

1. Danilov S. Doydum dyono: kepsenner. Kylaas taghynan aaghyga kyomyo. Yakutsk: Knizhnoye izdatelstvo, 1991.

2. Kay Won Lee. Korean Onomatopoeia and Mimesis, 2007.

3. Kharytonov, L.N. Grammatika sovremennogo yakutskogo yazika. Phonetika. Morphologiya (Grammar of the Modern Yakut Language. Phonetics. Morphology). Moscow: Nauka, 1982.

4. Kharytonov, L.N. Neizmenyaemiye slova v yakutskom yazike (Unchangeable words in the Yakut language). Yakutsk: Gos. izd-vo YASSR, 1943.

5. Neustroev N.D. Tyoryoyobut sirber, taptallakh dyommor. Pyesalar, kepseenner, tylbaas, khohonnor, suruktar. Yakutsk: Bichik, 1995.

6. Suorun Omolloon. Kepseenner. - Yakutsk: Knizhnoye izd-vo Respubliki Sakha, 1955.

7. Yakutskiy yazik: Lexikologiya, Lexikographiya: M.S Voronkina, E.I. Korkina, P.A. Sleptsov. - Yakutsk: YNC SD RAS, 1989.

8. 김동리. 한국의 명단편. 국일문학사, 1990.

9. 채완. 한국어의 의성어와 의태어. 서울대학교 출판부, 2003. 